\title{
STRATEGI PENINGKATAN PENERIMAAN RETRIBUSI ASET TETAP TANAH DI KABUPATEN LOMBOK BARAT
}

\author{
Hailuddin*, Imam Kholbi, Ade Paranata, dan Sofiati Wardah.
}

Fakultas Ekonomi dan Bisnis, Universitas Mataram

*penulis korespondensi: didin_unram@gmail.com

\begin{tabular}{ll}
\hline Kata Kunci: & ABSTRAK \\
Asset retribution, internal & This research is about strategies to increase levies of fixed \\
and external factors, & assets / land in West Lombok Regency, with the aim to find \\
Strength, Weakness, & out strategies to increase levies from the management of \\
Opportunity, Treath & fixed assets (land) in West Lombok Regency. The study is \\
quantitative descriptive, using time series data for 6 years, & 2012-2017. Besides using secondary data, it is also \\
& strengthened by primary data which is collected through \\
& library studies, documentation, interviews and \\
& questionnaires. Data analysis uses SWOT analysis by \\
& identifying internal factors to determine aspects of \\
& strengths and weaknesses, as well as external factors to \\
& determine aspects of opportunity and threats. The results \\
& showed that there were 9 strategies that could be used to \\
increase revenue from user fees for land use, including \\
utilizing scientific and technological advances, increasing \\
the number and quality of human resources in managing \\
levies, working with related parties, improving local \\
government land certification, land inventory local \\
government, increase land rental rates and improve \\
supervision of land assets. The results of this study are \\
expected to be followed up by the West Lombok Regional \\
Government in order to increase revenue from the use of \\
regional wealth that is getting better
\end{tabular}




\section{LATAR BELAKANG}

Otonomi Daerah pada dasarnya memberikan kesempatan pada daerah untuk mengembangkan diri. Karena itu tujuan otonomi daerah berorientasi pada pembangunan, yaitu pembangunan dalam arti luas yang meliputi semua segi kehidupan masyarakat. Oleh sebab itu, daerah diberikan sumber-sumber keuangan untuk dapat membiayai penyelenggaraan pemerintahan dan pembangunan, sehingga setiap daerah memiliki kemampuan untuk menggali sumber-sumber keuangan sendiri, mengelola dan menggunakan keuangan sendiri yang memadai untuk membiayai penyelenggaraan pemerintahan di daerahnya, sehingga ketergantungan pada pemerintah pusat dapat diminimalkan (Wardani.2010).

Pendapatan Asli Daerah (PAD) merupakan salah satu sumber penerimaan daerah yang meliputi, pajak daerah, retribusi daerah, hasil pengelolaan kekayaan daerah yang dipisahkan, dan lain-lain PAD yang sah. Umumnya PAD setiap daerah masih relatif kecil, hal ini disebabkan karena belum optimal, efisiensi, efektivnya penerapan prinsip penghematan. Oleh sebab itu, perlu adanya upaya meningkatkan PAD khususnya yang berasal dari pajak daerah dan retribusi daerah tanpa harus menambah beban masyarakat (Ningrum.2010).

Retribusi daerah merupakan salah satu sumber PAD yang bisa diandalkan karena setiap tahunnya mampu memberikan sumbangan yang relatif besar bagi penerimaan daerah termasuk di Lombok Barat. Pemerintah daerah Kabupaten Lombok Barat memberikan wewenang kepada BPKAD (Badan Pengelolaan Keuangan dan Aset Daerah) untuk mengelola retribusi pemakaian kekayaan daerah secara profesional dan transparan dalam rangka optimalisasi serta upaya peningkatan terhadap pendapatan asli daerah. Pengelolaan retribusi yang optimal diharapkan mampu mewujudkan otonomi daerah yang baik serta pembangunan daerah yang merata sehingga dapat digunakan untuk kepentingan masyarakat. Retribusi daerah pada dasarnya dapat dikelompokkan menjadi 3 (tiga) bagian yaitu: Retribusi Jasa Umum, Retribusi Jasa Usaha, Retribusi Perijinan Tertentu (Perda Lombok Barat No. 66 tahun 2001).

Sebagian besar kebutuhan APBD setiap daerah di biayai dana alokasi dari pusat. Dalam banyak hal, dana alokasi dari pusat tidak sepenuhnya dapat diharapkan untuk menutup seluruh kebutuhan pengeluaran daerah. Oleh karena itu dukungan dari masyarakat melalui Retribusi daerah mesti terus harus digalakkan, dengan tetap menjaga kestabilan iklim investasi dan menghindari terjadinya tumpang tindih dengan pemerintah pusat, serta tidak merintangi arus jasa antar daerah. Dengan katentuan tersebut, Kabupaten Lombok Barat diharapkan akan lebih mampu menggali sumber pembiayaannya untuk membiayai kebutuhan pengeluaran dalam melaksanakan kegiatan pembangunannya. Disisi lain akan dapat memberikan kepastian bagi masyrakat dan dunia usaha yang selanjutnya akan dapat meningkatkan kesadaran masyarakat dalam memenuhi kewajiban Retribusinya.

Sebagaimana diketahui, PAD Lombok Barat saat ini sebagian besar penerimaanya dari pendapatan pajak, disusul pendapatan dari hasil pengelolaan kekayaan daerah yang dipisahkan, baru disusul oleh retribusi daerah dan lain-lain pendapatan yang sah. Meskipun retribusi kontribusinya saat ini masih kecil (sekitar $5,4 \%$ namun potensi untuk menjadi sumber penerimaan daerah potensial 
dimasa mendatang cukup terbuka. Hal ini tidak lepas banyak sumber-sumber yang belum digali secara optimal. Salah satunya adalah retribusi pemakaian kekayaan daerah berupa tanah yang merupakan bagian dari retribusi jasa usaha. Banyaknya kasus-kasus sengketa tanah di Kabupaten Lombok Barat membuat realisasi dari penerimaan retribusi pemakaian kekayaan daerah ini tidak bisa memenuhi target yang ditetapkan. Berbagai kasus yang timbul terkait dengan tanah ini antar lain banyaknya objek retribusi sudah beralih fungsi, objek tanah tidak sesuai dengan kelas tanah kontrak sewa lelang, dan juga banyaknya objek tanah yang masih dalam sengketa dengan masyarakat sehingga sewa tanah tidak bisa dipungut.

Permasalahan sewamenyewa pertanahan didaerah ini hampir terjadi disemua daerah dengan pola yang tidak jauh beda. Oleh karena itu menjadi tugas Pemda masing-masing daerah untuk dapat menuntaskan masalah ini sebelum keadaannya menjadi lebih berat. Sementara disisi lain sebagian daerah masih mengandalkan penerimaan dari sewa aset lahan ini menjadi sumber penerimaan daerahnya. Dengan uraian latar belakang tersebut penulis tertarik untuk mengkaji lebih mendalam strategi yang bisa digunakan untuk meningkatkan penerimaan retribusi pemakaian kekayaan daerah, khususnya di Lombok Barat. Dengan demikian diharap mampu mencapai tujuan penelitian yaitu untuk mengetahui strategi dalam meningkatkan penerimaan retribusi aset tanah yang mampu meningkatkan pendapatan asli daerah akan bisa dicapai.

\section{TINJAUAN PUSTAKA}

1. Manajemen Strategis
Manajemen strategis pada dasarnya berhubungan dengan suatu kegiatan pengambilan keputusan/tindakan yang diperlukan guna mengatasi masalahmasalah yang dihadapi baik oleh seseorang, kelompok, organisasi atau bahkan pemerintah dalam rangka mewujudkan tujuan yang telah direncanakan. (Olsen dan Eadie dalam Suryani.2009:25). Sebenarnya manajemen strategis sama saja dengan manajemen lainnya, yang berfungsi untuk merencanakan, mengorganisasikan, melaksanakan, dan mengendalikan hal-hal strategis. Pemanfaatan manajemen strategis ke dalam organisasi sektor publik sendiri baru dimulai pada awal tahun 1980-an (Suryani.2009; 27). Penerapan manajemen strategis sebagai strategik planning belum menjadi suatu tradisi bagi birokrasi. Sedangkan dalam rangka memberikan pelayanan kepada publik yang lebih baik di masa mendatang, tradisi strategic planning bagi birokrasi akan sangat bermanfaat terutama dalam memacu pola berfikir strategis mengenai apa misi utama birokrasi yang hendak dicapai, tujuan jangka panjang dan pendeknya, rencana-rencana strategis, dan rencana-rencana operasional, khususnya progarm-program dan proyeknya. Relevansi manajemen strategis bagi birokrasi kiranya telah menemukan momentumnya saat ini mengingat sifat interconnectedness di lingkungan birokrasi juga semakin mengemuka dari waktu kewaktu.

Terdapat empat pendekatan dasar untuk mengenali isu strategis Menurut (Bryson 1995:66-68 dalam Suryani.2009), yaitu :

1). Pendekatan langsung (direct approach), meliputi jalan lurus dari ulasan terhadap mandat, misi dan SWOT hingga identifikasi isu-isu strategis. Pendekatan langsung dapat bekerja di dunia yang pluralistik, partisan, terpolitisasi, dan relatif terfragmentasi di sebagian besar 
organisasi publik, sepanjang ada koalisi dominan yang cukup kuat dan cukup menarik untuk membuatnyabekerja.

2). Pendekatan tidak langsung (indirect approach), hampir sama dengan pendekatan langsung dan biasanya dilakukan bersama dengan pendekatan langsung, hanya tidak dibentuk tim khusus. Kedua pendekatan ini yang paling banyak digunakan untuk organisasi Pemerintah dan organisasi nirlaba.

3). Pendekatan sasaran (goals approach), lebih sejalan dengan teori pendekatan konvensional, yang menetapkan bahwa organisasi harus menciptakan sasaran dan tujuan bagi dirinya sendiri dan kemudian mengembangkan strategi untuk mencapainya. Pendekatan ini dapat bekerja jika ada kesepakatan yang agak luas dan mendalam tentang sasaran dan tujuan organisasi, serta jika sasaran dan tujuan itu cukup terperinci dan spesifik untuk memandu pengembangan strategi.

4). Pendekatan visi kebersilan (vision of success), dimana organisasi mengembangkan suatu gambar yang sangat berhasil memenuhi misinya. Pendekatan ini lebih mungkin bekerja dalam organisasi nirlaba ketimbang organisasi sektorpublik.

Berdasarkan uraian di atas pendekatan yang paling tepat digunakan dalam penelitian ini adalah pendekatan langsung, sebab pada birokrasi publik pada umumnya ditangani oleh unit tertentu yang telah mendapatkan pengesahan dari para decision maker. Namun yang perlu diingat bahwa proses manajemen strategis apa pun akan bermanfaat hanya jika proses manajemen strategis membantu berpikir dan bertindak secara strategis kepada orang-orang penting pembuat keputusan.

\section{PerumusanStrategi}

Perumusan strategi adalah proses memilih pola tindakan utama (strategi) untuk mewujudkan visi dan misi organisasi. Kenyataannya perumusan strategi dapat dimulai dari mana saja, bisa dimulai dari kondisi lingkungan internal (Strength, Weakness) dan kondisi lingkungan eksternal (Opportunity, Threat) atau bahkan strategi itu sendiri. Namun yang terpenting pilihan strategi akhirnya harus saling sesuai dengan Kekuatan, Kelemahan, Peluang, Ancaman yang ada dan tujuan (visi-misi) yang ingin dicapai (Suryani.2009).

Perumusan strategi juga sering kali di tunjukkan sebagai perencanaan strategi atau jangka panjang. Proses perumusan strategi berurusan dengan pengembangan misi, tujuan, strategi dan kebijakan organisasi. Agar ini tercapai pembuat strategi harus menganalisis faktor-faktor strategis organisasi (kekuatan, kelemahan, peluang, dan ancaman kunci) pada situasi sekarang (Suryani.2009).

\section{Retribusi Daerah}

Retribusi merupakan pungutan daerah sebagai pembayaran atas jasa atau pemberian izin tertentu yang khusus disediakan dan/atau diberikan oleh Pemerintah daerah untuk kepentingan orang pribadi atau badan (Perda No. 28 Tahun 2009).

Jenis- jenis retribusi terbagi menjadi 3 kelompok yakni:

1. Retribusi Jasa Umum

Retribusi jasa umum adalah jasa yang diberikan atau disediakan oleh Pemerintah daerah untuk tujuan kepentingan dan kemanfaatan umum serta dapat dinikmati oleh orang pribadi atau badan. Retribusi jasa umum ditetapkan dengan Perda dengan kriteria berikut:

a. Retribusi jasa umum bersifat bukan pajak dan bersifat bukan retribusi Jasa usaha atau Perizinan tertentu

b. Jasa yang bersangkutan merupakan kewenangan daerah dalam rangka pelaksanaan desentralisasi

c. Jasa tersebut memberikan manfaat khusus bagi orang pribadi atau badan yang diharuskan membayar retribusi 
disamping untuk melayani kepentingan dan kemanfaatan umum

d. Jasa tersebut layak untuk diberikan retribusi

e. Retribusi tidak bertentangan dengan kebijakan nasional penyelenggaraannya

f. Retribusi dapat dipanggul secara efektif dan efisien, serta merupakan salah satu sumber pendapatan daerah yang potensial g. Pemungutan retribusi memungkinkan penyediaan jasa tersebut dengan tingkat dan atau kualitas pelayanan yang lebih baik

Sedangkan jenis-jenis Retribusi Jasa Umum antaranya: a. Retribusi pelayanan Kesehatan, b. Retribusi Pelayanan Persampahan / Kebersihan, c. Retribusi Penggantian Biaya Cetak Kartu Tanda Penduduk dan Akta Catatan Sipil, d. Retribusi Pelayanan Pemakaman dan Pengabuan Mayat, e. Retribusi Pelayanan Parkir diTepi Jalan Umum, dan f. Retribusi Pelayanan Pasar.

2. Retribusi Jasa Usaha

Retribusi ini merupakan jasa yang disediakan oleh Pemda dengan menganut prinsip-prinsip komersial karena pada dasarnya dapat disediakan pula oleh pihak swasta. Objek Retribusi jasa usaha yang disediakan oleh Pemda menganut prinsip komersial yang meliputi:

a. pelayanan dengan menggunakan atau memanfaatkan kekayaan daerah yang belum dimanfaatan secara optimal.

b. pelayanan oleh Pemerintah Daerah sepanjang belum disediakan secara memadai oleh pihak swasta.

Selanjutnya jenis-jenis Retribusi Jasa Usaha ini antara lain:a. Retribusi Pemakaian Kekayaan Daerah, b. Retribusi Pasar Grosirdan/atau Pertokoan, c. Retribusi Tempat Pelelangan, d. Retribusi Terminal, e. Retribusi Tempat Khusus Parkir, f. Retribusi Rumah Potong Hewan,

3. Retribusi Perijinan Tertentu

Retribusi perizinan tertentu adalah kegiatan tertentu Pemda dalam rangka memberikan izin kepada orang pribadi atau badan yang dimaksudkan untuk pembinaan, pengaturan, pengendalian, dan pengawasan atas kegiatan pemanfaatan ruang, penggunaan sumber daya alam, barang, prasarana, saran atau fasilitas tertentu guna melindungi kepentingan umum dan menjaga kelestarian lingkungan.

Kriteria-kriteria Retribusi Perijinan Tertentu meliputi:

a. perizinan tersebut termasuk kewenangan pemerintahan yang diserahkan kepada daerah dalam rangka desentralisasi.

b. perizinan tersebut benar-benar diperlukan guna melindungi kepentingan umum

c. biaya yang menjadi beban daerah dalam penyelenggaraan izin tersebut dan biaya untuk menanggulangi dampak negatif dari pemberian izin tersebut.

Jenis-Jenis Retribusi Perizinan tertentu antaranya: a. Retribusi Izin Mendirikan Bangunan, b. Retribusi Izin Tempat Penjualan Minuman Keras, c. Retribusi Izin Gangguan, d. Retribusi Izin Trayek, e. Retribusi Izin Usaha Perikanan.

4. Retribusi Penggunaan Kekayaan Daerah Retribusi Pemakaian Kekayaan Daerah merupakan jenis retribusi jasa usaha, yang merupakan pungutan daerah atas pemakaian barang-barang bergerak dan/atau tidak bergerak termasuk ruang diatasnya yang dimiliki/dikelola dan/atau dibawah penguasaan baik langsung maupun tidak langsung oleh Pemda yang disediakan untuk dan/atau dapat dimanfaatkan oleh masyarakat guna menunjang berbagai keperluan yang bersangkutan dalam rangka meningkatkan kesejahteraan umum.

Objek Retribusi Pemakaian Kekayaan Daerah (Perda Kabupaten Lombok Barat No 4 Tahun 2011) meliputi: a. Pemakaian tanah, b. Pemakaian peralatan Dinas 
Pekerjaan Umum, c. Pemakaian Gedung, d. Penggunaan Alat laboraturium.

5. Aset Tanah

Secara umum aset adalah barang atau suatu barang yang mempunyai nilai ekonom, nilai komersil, atau nilai tukar yang dimiliki oleh badan usaha, instansi atau individu. Pengertian ini pada dasarnya juga berlaku pula untuk aset yang dimiliki oleh negara berdasarkan syarat-syarat tertentu. Aset juga merupakan barang atau benda, yang terdiri dari benda bergerak dan benda tidak bergerak, baik yang berwujud maupun yang tidak berwujud, yang tercakup didalam aktiva atau kekayaan dari suatu instansi, organisasi badan usaha atau individu perorangan. Aset berwujud dapat berupa tanah, bangunan, mesin, peralatan, dan kendaraan. Sedangkan aset tidak berwujud meliputi hak paten, hak cipta, hak merek dagang, budaya dan reputasi. (Fajri, 2017; 37).

\section{METODE PENELITIAN}

Penelitian ini menggunakan metode deskriptif dengan pendekatan kuantitatif. Metode ini berfungsi untuk mendeskripsikan atau memberi gambaran terhadap objek yang diteliti melalui data atau sampel yang telah terkumpul sebagaimana adanya, tanpa melakukan analisis dan membuat kesimpulan yang berlaku (Sugiyono, 2018:147).

Lokasi penelitian di Kabupaten Lombok Barat. Alasan pemilihan Kabupaten Lombok Barat sebagai objek adalah karena banyaknya kasus aset Pemda berupa tanah bermasalah yang setiap tahunnya terus bertambah. Bahkan di tahun 2016 jumlah aset yang bermasalah dan berujung sengketa dimeja hijau sebanyak 13 kasus.

Data yang digunakan adalah data time series selama 6 tahun mulai tahun 2012 sampai dengan 2017 yaitu data target dan realisasi Retribusi Penggunaan Kekayaan Daerah Kabupaten Lombok Barat Tahun
2012 - 2017 dan data kualitatif yang berupa hasil wawancara dari beberapa sumber atau key person (informan kunci). Pengumpulannya menggunakan teknik studi kepustakaan, metode dokumentasi, wawancara dan kuisoner.

Key Person yang dipilih secara purposive yaitu :

1. Staf bidang perencanaan pemanfaatan dan pengadaan Kantor Bupati Lombok Barat.

2. Kepala dan staf bidang pengamanan, pemindahtanganan \& penata usahaan,

3. Masyarakat yang menyewa tanah pemda.

4. Informan lain yang punya kepentingan di lapangan.

Variable penelitian adalah tanah Pemda Kabupaten Lombok Barat yang disewakan kepada masyarakat untuk kegiatan usaha dan penerimaan penyewaan tanah masuk kedalam retribusi pemakaian kekayaan daerah yang dikelola oleh Badan Pengelolaan Keuangan dan Aset Daerah (BPKAD).

Data yang terkumpul dianalisis dengan analisis SWOT untuk mengkaji faktor internal sehingga diketahui apa saja faktor kekuatan (Strength) dan kelemahan (Weaknes), juga menganalisa faktor eksternal untuk mengetahui peluang (Oportunity) dan ancaman ( Treat ) yang di hadapi, sebagaimana terlihat dalam matrik berikut.

\begin{tabular}{|c|c|c|}
\hline IFAS & \begin{tabular}{|l|} 
STRENGTHS (S) \\
Tentukan faktor-faktor \\
kekuatan internal \\
\end{tabular} & $\begin{array}{l}\text { WEAKNEES }(W) \\
\text { Tentukan faktor-faktor } \\
\text { kelemahan internal }\end{array}$ \\
\hline \begin{tabular}{|l|} 
OPPORTUNIES (O) \\
Tentukan faktor-faktor \\
peluangekternal
\end{tabular} & $\begin{array}{l}\text { STRATEGI S-O } \\
\text { Ciptakan strategi yang } \\
\text { menggunakan kekuatan utk } \\
\text { memanfaatkan Peluang }\end{array}$ & $\begin{array}{l}\text { STRATEGI W-O } \\
\text { Ciptakan strategi yang } \\
\text { meminimalkan kelemahan utk } \\
\text { memanfaatkan peluang }\end{array}$ \\
\hline \begin{tabular}{|l|} 
THREATS $(T)$ \\
Tentukan faktor-faktor \\
peluangekternal
\end{tabular} & \begin{tabular}{|l|} 
STRATEGI S-T \\
Cipatakan strategi yang \\
menggunakan kekuatan untuk \\
mengatasi acaman
\end{tabular} & $\begin{array}{l}\text { STRATEGI W-T } \\
\text { Ciptakan strategi yang } \\
\text { meminimalkan kelemahan } \\
\text { dan menghindari ancaman }\end{array}$ \\
\hline$F_{t}$ & $\begin{array}{l}\text { (ysis Summary) } \\
\text { alysis Summary) }\end{array}$ & \\
\hline
\end{tabular}

\section{HASIL PENELITIAN DAN PEMBAHASAN}

1. Deskripsi Data 
Berdasarkan observasi dan evaluasi dari wawancara dengan beberapa narasumber dapat diuraikan faktor internal dan eksternal terkait masalah penelitian sebagai berikut:

A. Faktor Kekuatan Internal (Strenght)

Lingkungan internal merupakan lingkungan yang relatif dapat di kendalikan oleh perusahaan atau organisasi yang terdiri dari kumpulan kekuatan dan kelemahan yang dimiliki. Faktor kekuatan internal dalam rangka pengelolaan aset tanah di Kabupaten Lombok Barat antara lain;

1. Adanya Peraturan Daerah yang jelas (S.1), yaitu Peraturan Daerah Kabupaten Lombok Barat No 4 tahun 2011 tentang retribusi jasa usaha.

2. Adanya Pembagian Tugas (S.2), yaitu pembagian tugas dan fungsi BPKAD khususnya bidang yang berkaitan langsung dengan pengelolaan retribusi pemakaian kekayaan daerah.

3. Ketersediaan Aset Tanah. (S.3), yaitu ketersediaan aset tanah di Kabupaten Lombok Barat untuk disewakan.

4. Sarana dan Prasarana. (S.4), yaitu sarana dan prasarana dalam pengelolaan retribusi tanah ini seperti perangkat TI (laptop), kendaraan operasional dan lain-lain.

5. Keamanan Tanah. (S.5), yaitu pengamanannya berupa pemantauan, penertiban terhadap penggunaan, pemanfaatan, pemeliharaan aset Pemda.

B. Faktor Kelemahan Internal (Weakness)

Faktor kelemahan internal dalam pengelolaan retribusi pemakaian kekayaan daerah (tanah) di Lombok Barat, antaranya;

1. Inventarisasi (W.1), inventarisasi aset penting dilakukan agar aset-aset yang dimiliki Pemda dapat dimanfaatkan oleh Pemda untuk meningkatkan PAD.

2. Minimnya SDM (W.2), keterbatasan SDM ini terutama untuk tenaga lapangan, yang membuat pegawai kewalahan dalam melaksanakan tugas yang di embannya
3. Kualitas SDM (W.3). kualitas sumber daya manusia yang ada masih kurang memahami betul tugasnya, karena latar belakang keilmuannya yang beda.

4. Pengawasan Pemanfaatan Aset (W.4), pengawasan pemanfaatan aset Pemda saat ini masih kurang baik karena organ yang ada belum bekerja maksimal.

5. Penetapan Harga Sewa (W.5). Penetapan harga sewa tanah tahunan yang di tetapkan oleh Pemda masih relatif kecil dan tidak berorientasi pada harga pasar.

6. Sanksi (W.6). saat ini Pemda belum mampu menetapkan sanksi karena alasan sosial dan tidak tega terhadap wajib retribusi.

C. Faktor eksternal Peluang (Opportunity)

Faktor eksternal peluang yang di miliki dalam rangka pengelolaan retribusi pemakaian kekayaan daerah/tanah di Lombok Barat, antaranya;

1. Minat Investasi (O.1), masyarakat lebih tertarik menyewa tanah Pemda karena tarif sewa tanah yang dikenakan lebih murah dibandingkan harga pasar, dan mereka tertarik untuk memanfaatkan sebagai inventasi.

2. Kesadaran Membayar Retribusi (O.2). Kesadaran wajib retribusi dalam membayar sewa cukup baik dan tepat waktu.

3. Kemajuan Ilmu Teknologi (O.3). penggunaan sistem komputerisasi akan meningkatkan efisiensi organisasi dalam meningkatkan pelayanan pada masyarakat.

4. Tarif Sewa Lebih Murah (O.4). Penetapan tarif sewa yang lebih murah menjadi peluang bagi Pemda dan lebih mudah memasarkan tanah Pemda untuk disewakan.

5. Kontribusi terhadap PAD (O.5), adanya retribusi daerah dari pemakaian kekayaan daerah/tanah, merupakan salah satu peluang daerah dalam meningkatkan PAD melalui penerimaan retribusi pemakaian kekayaan daerah dimaksud. 


\section{Faktor Ancaman Eksternal (Threats)}

Faktor ancaman ekternal yang di hadapi dalam rangka pengelolaan retribusi penggunaan kekayaan daerah/tanah di Lombok Barat adalah;

1. Objek Tanah Yang Beralih Fungsi (T.1). Saat ini cukup banyak tanah Pemda yang beralih fungsi menjadi gedung pemerintahan, dan untuk keperluan umum seperti lapangan dan lain-lain.

2. Tanah Sengketa (T.2), sengketa ini timbul karena organ yang mengurus tanah ini sering berubah-ubah yang awalnya di bagian umum kemudian menjadi DPPKAD, Kantor Aset dan sekarang menjadi BPKAD sehingga surat-surat tanah Pemda tidak terdata dengan baik.

3. Produktifitas Tanah (T.3), beberapa tanah Pemda yang disewakan ternyata ada yang kurang produktif karena sistem pengairan kurang baik, pengaruh air payau (terutama yang dekat laut) dan juga karena penggunaan obat-obat kimia.

4. Dokumen Kepemilikan Tanah (T.4), proses pensertifikatan tanah Pemda yang lambat akibat dokumen-dokumen yang dibutuhkan belum lengkap.

5. Pengklaiman Pihak Tertentu (T.5). Beberapa tanah Pemda yang diklaim oleh pihak ketiga disebabkan kurang lengkapnya dokumen. Dan juga masyarakat awalnya menyewa tanah Pemda karena sudah lama menyewa, mereka mendirikan bangunan di atasnya dan mengklaim tanah tersebut adalah tanah milik mereka.

6. Tarif sewa tanah (T.6). Rendahnya tarif sewa lelang tanah yang berlaku saat ini. Hal ini bisa menjadi ancaman bagi Pemda dalam rangka peningkatan realisasi retribusi pemakaian kekayaan daerah.

7. Sertifikat Tanah (S.7). Dari pantauan lapangan memang masih ada tanah Pemda yang belum memilki sertifkat namun tidak dipublikasi karena alasan keamanan.

Dengan dasar uraian diatas dapat dianalisis beberapa faktor SWOT yang dapat digunakan didalam penentuan stategi alternative. Namun sebelumnya di lakukan pembobotan dan pemeringkatan guna mengetahui tingkat kepentingan masing-masing faktor yang didapatkan dan juga untuk mengetahui tingkat pengaruh faktor strategi terhadap lingkungannya.

Langkah pertama untuk pembobotan, pemeringkatan dan score. Bobot ditentukan berdasarkan tingkat kepentingan atau urgensi penanganan dengan skala 1 sampai dengan 5 (1= tidak penting, 5=sangat penting) yang dinilai oleh responden internal. Kemudian langkah yang kedua adalah menjumlahkan bobot kekuatan dan bobot kelemahan. Kemudian dihitung bobot relative untuk masing-masing indikator yang terdapat pada kekuatan dan kelemahan, sehingga total nilai bobot tersebut menjadi $100 \%$. Dengan cara yang sama dihitung bobot dan bobot relatif untuk peluang dan acaman.

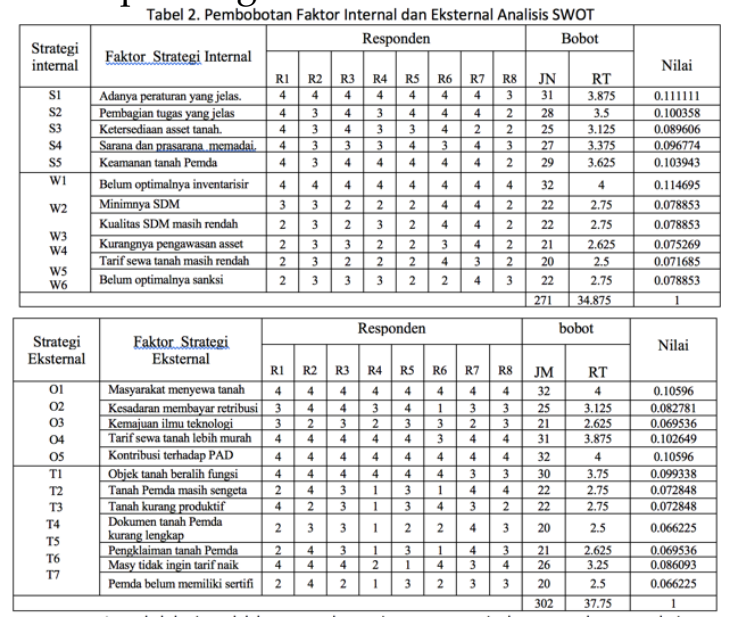

Langkah ketiga adalah menentukan rating atau pemeringkatan, untuk mengetahui besarnya pengaruh indikator strategi terhadap lingkungannya. Nilai indikator diberi nilai 1 sampai dengan 4 yang di dinilai oleh responden eksternal. Nilai 1 bila indikator memiliki pengaruh yang kecil dan nilai 4 memiliki pengaruh yang sangat besar. 
Vol. 1 No. 2, September 2019

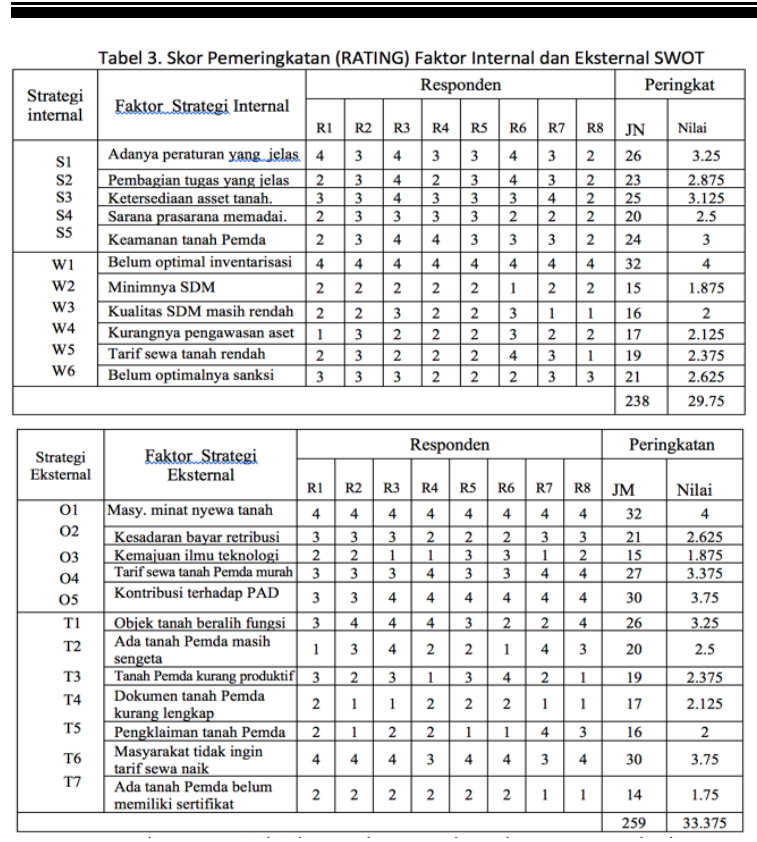

Kemudian mencari nilai skor untuk menentukan seberapa penting dan berpengaruh indikator-indikator atau faktor SWOT terhadap objek penelitian dengan cara mengalikan jumlah bobot setiap indikator dengan peringkat setiap indikator sehingga didapatkan hasil atau nilai dimana semakin tinggi nilai menggambarkan indikator SWOT tersebut memiliki tingkat keterkaitan yang kuat dan sangat berpengaruh terhadap lingkungannya.

\begin{tabular}{|c|c|c|c|c|}
\hline \multicolumn{2}{|c|}{ Strenght (Kekuatan) } & \multirow{2}{*}{$\begin{array}{c}\text { Bobot } \\
0.111111 \\
\end{array}$} & \multirow{2}{*}{\begin{tabular}{|c|} 
Peringkat \\
3.25 \\
\end{tabular}} & \multirow{2}{*}{$\begin{array}{c}\text { Skor } \\
0.361111 \\
\end{array}$} \\
\hline S1 & Adanya peraturan yang mengatur. & & & \\
\hline S2 & Pembagian tugas yang jelas & 0.100358 & 2.875 & 0.288529 \\
\hline S3 & Ketersediaan aset tanah. & 0.089606 & 3.125 & 0.280019 \\
\hline S4 & Sarana dan prasarana yang _memadai. & 0.096774 & 2.5 & 0.241935 \\
\hline S5 & Keamanan tanah Pemda & 0.103943 & 3 & 0.311829 \\
\hline \multicolumn{5}{|c|}{ Weakness (Kelemahan) } \\
\hline W1 & Belum optimalnya inventarisir & 0.114695 & 4 & 0.45878 \\
\hline W2 & Minimnya SDM & 0.081181 & 1.875 & 0.147849 \\
\hline W3 & Kurangnya pengawasan aset & 0.077491 & 2.125 & 0.159947 \\
\hline W4 & Tarif sewa tanah masih rendah & 0.073801 & 2.375 & 0.170252 \\
\hline W5 & Belum optimalnya sanksi & 0.081181 & 2.625 & 0.206989 \\
\hline W6 & Kualitas SDM masih rendah & 0.081181 & 2 & 0.157706 \\
\hline & Total & 1,00 & & 2.784946 \\
\hline \multicolumn{5}{|c|}{ Faktor Strategi Eksternal } \\
\hline & Opportunities (Peluang) & Bobot & Peringkat & Skor \\
\hline 01 & Masyarakat ingin menyewa tanah & 0.105263 & 4 & 0.421052 \\
\hline 02 & Kesadaran membayar retribusi & 0.082237 & 2.625 & 0.215872 \\
\hline 03 & Kemajuan ilmu teknologi & 0.069767 & 1.875 & 0.130813 \\
\hline 04 & Tarif sewa tanah Pemda lebih murah & 0.101974 & 3.375 & 0.344162 \\
\hline 05 & Kontribusi terhadap PAD & 0.105263 & 3.75 & 0.394736 \\
\hline \multicolumn{5}{|c|}{ Threats (Ancaman) } \\
\hline $\mathrm{T} 1$ & Objek tanah beralih fungsi & 0.095395 & 3.25 & 0.310034 \\
\hline $\mathrm{T} 2$ & Ada tanah Pemda yang masih sengeta & 0.072368 & 2.5 & 0.18092 \\
\hline $\mathrm{T} 3$ & Tanah Pemda kurang produktif & 0.072368 & 2.375 & 0.171874 \\
\hline T4 & Dokumen tanah Pemda kurang lengkap & 0.065789 & 2.125 & 0.139802 \\
\hline T5 & Pengklaiman tanah Pemda & 0.069079 & 2 & 0.138158 \\
\hline T6S & Masyarakat tidak ingin tarif sewa naik & 0.085526 & 3.75 & 0.320723 \\
\hline $\mathrm{T} 7$ & Ada tanah Pemda belum memiliki sertifikat & 0.065789 & 1.75 & 0.115131 \\
\hline & Total & 1 & & 2.883277 \\
\hline
\end{tabular}

Hasil pembobotan terhadap faktor-faktor yang dianalisis, diperoleh hasil bahwa faktor-faktor eksternal (peluang dan ancaman) lebih besar pengaruhnya di bandingkan dengan faktor-faktor internal (kekuatan dan kelemahan) terhadap pengelolaan retribusi pemakaian kekayaan daerah (tanah). Rasio faktor eksternal lebih besar (2.883) dibanding faktor internal (2.784). Ini menunjukan adanya pengaruh yang lebih kuat dalam pengelolaan ratribusi pemakaian kekayaan daerah dimaksud.

Setelah pembobotan dan pemeringkatan, langkah selanjutnya menganalisis faktor-faktor dengan menggunakan matrik SWOT dan menciptakan alternatif-alternatif strategi dari beberapa kuandran yaitu strategi S-O dimana strategi ini dciptakan dengan menggunakan kekuatan untuk memanfaatkan peluang, dan strategi W-O dimana strategi yang diciptakan dengan meminimalkan kelemahan untuk memanfaatkan peluang. Selanjutnya strategi S-T dimana strategi ini diciptakan dengan menggunakan kekuatan untuk mengatasi ancaman dan stratgi W-T dimana strategi ini muncul dengan meminimalkan kelemahan dan mengatasi ancaman. Dengan demikian diperoleh hasil seperti terlihat dalam matrik SWOT berikut.

\begin{tabular}{|c|c|c|c|}
\hline \multicolumn{4}{|c|}{ Tabel 5 Matrik SWOT } \\
\hline Faktor Ekstemal & & \begin{tabular}{|l|} 
Strenght (S) \\
S.1 Adanya Peraturan yang jelas \\
S.2 Pembagian tugas yg jelas. \\
S.3 Ketersediana sate tanah. \\
S.4 Sarana dan prasarana. \\
S.5 Keamanan Tanah.
\end{tabular} & 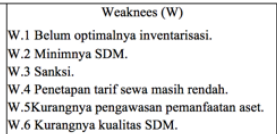 \\
\hline \multicolumn{2}{|c|}{\begin{tabular}{l}
\multicolumn{1}{c}{ Opportunity $(\mathrm{O})$} \\
O.1. Banyak masy. ingin menyewa tanah. \\
O.2 Kesedaran membayar retribusi. \\
O.3 Kemajuan ilmu teknologi. \\
O.4 Tarif sewa lebih murah \\
O.5 Kontribusi Terhadap PAD
\end{tabular}} & 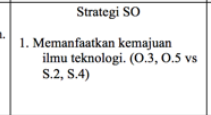 & 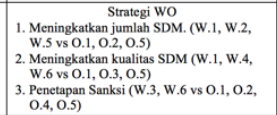 \\
\hline \multicolumn{2}{|c|}{$\begin{array}{l}\text { Treats (T) } \\
\text { T.1. Objek tanah beralih fungsi. } \\
\text { T.2. Ada tanah yang bersengketa. } \\
\text { T.3. Tanah kurang produktif. } \\
\text { T.4. Dokumen kepemilikan belum lengkar } \\
\text { T.5. Pengkkaiman tanah. } \\
\text { T.6. Masy tdk ingin tarif sewa naik. } \\
\text { T.7. Tanah belum memiliki sertif. } \\
\end{array}$} & 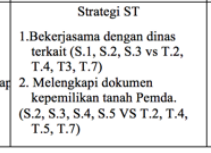 & 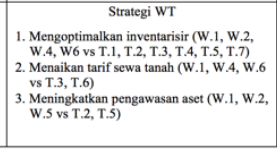 \\
\hline \multicolumn{4}{|c|}{ Tabel 6. Matrik Kesesuaian SWOT } \\
\hline Unsur & & Strength $(S)$ & Weaknesses $(W)$ \\
\hline$O_{p p o r t u n i t i e s ~(O)}$ & & $\begin{array}{l}\text { Strategi-SO } \\
\text { 1. S2, S4 vs O3, O5 }\end{array}$ & $\begin{array}{c}\text { Strategi-WO } \\
\text { 1. W1, W2, W5 vs O1, O2, O5 } \\
\text { 2. W1, W4, W6 vs O1, O3, O5 } \\
\text { 3. W3, W6 vs O1, O2, O4, O5 }\end{array}$ \\
\hline Threats (T) & $\begin{array}{l}\text { 1. S1, S } \\
\text { 2. S2, S }\end{array}$ & $\begin{array}{c}\text { Strategi-ST } \\
\text { S2, S3 vs2, T3, T4, T7 } \\
\text { S3, S4, S5 vs T2, T4, T5, T7 }\end{array}$ & $\begin{array}{c}\text { Strategi-WT } \\
\text { 1. W1, w2, W4, W6 v v1 T1, T2, T3, T4, } \\
\text { T5, T7 } \\
\text { 2. W1, W4, W6 v T3, T6 } \\
\text { 3. W1, W2, W5 vs T2, T5 }\end{array}$ \\
\hline
\end{tabular}

\section{Penerapan Skenario Strategi}


Berdasarkan analisis matrik SWOT pengelolaan retribusi pemakaian kekayaan daerah (tanah) pada tabel 5 ditentukan 9 (sembilan) skenario strategi dengan penjelasan masing-masing strategi sebagai berikut:

\section{Strategi Strenght - Opportunity (SO)}

Strategi yang menggunakan kekuatan untuk memanfaatkan peluang dalam pengelelolaan retribusi penggunaan kekayaan daerah, dilakukan tindakan berikut:

1). Memanfaatkan kemajuan ilmu teknologi

Penggunaan sistem teknologi informasi berbasis online kini sudah tidak terhindar lagi, karena hampir seluruh sektor kegiatan masyarakat saat ini bisa dikatakan sudah menggunakannya. Dan sistem ini bisa mempermudah pekerjaan di berbagai sektor, termasuk pemerintahan. Oleh sebab itu Pemda Lombok Barat perlu memanfaatkan kemajuan ilmu teknologi yang semakin lama semakin berkembang (O3) yang dapat mempermudah pemerintah daerah dan masyarakat di dalam pengelolaan retribusi demi peningkatan penerimaan pendapatan asli daerah (O5) tentu dengan pembagian pembagian tugas yang jelas (S2) dengan ketersediaan sarana dan prasarana yang dapat menunjang pemanfaatan teknologi (S4).

2. Strategi Weaknees - Oportunity (WO)

Strategi ini dijalankan dengan meminimalkan kelemahan untuk memanfaatkan peluang dalam pengelolaan retribusi pemakaian kekayaan daerah, dengan strategi yang dapat dilakukan yaitu:

1). Meningkatan Kuantitas atau Jumlah SDM.

Ketersediaan sumber daya manusia khususnya di dalam bidang-bidang yang berakaitan dengan pengelolaan retribusi ini adalah penting agar pengelolaan retribusi pemakaian kekayaan daerah dapat dijalankan dengan optimal. Beberapa kelemahan disini Pemda yaitu belum optimalnya inventarisasi (W1), minimnya SDM (W2), dan masih kurangnya pengawasan pemanfaatan aset (W5), maka perlu dilakukan peningkatan jumlah sumber daya manusia untuk mengatasi kelemahan yang dimiliki dan memanfaatkan peluang berupa tingginya minat masyarakat penyewa tanah pemda (O1), adanya kesadaran masyarakat dalam membayar retribusi $(\mathrm{O} 2)$, dan peningkatan penerimaan terhadap PAD (O5). Oleh karena itu sangat penting Pemda untuk berbenah mengatasi kelemahan ini demi memanfaatkan peluang yang ada demi pencapaian target penerimaan retribusi daerah.

2). Meningkatkan Kualitas Sumber Daya Manusia.

Peningkatan kualitas SDM disini berkaitan dengan peningkatan kualitas ilmu pengetahuan teknologi dan pemahaman tentang pengelolaan retribusi daerah. Dengan demikian akan dapat mengatasi beberapa kelemahan internal yang ada selama ini seperti belum optimalnya inventarisasi (W1), penetapan tarif sewa yang rendah (W4), dan kurangnya kualitas SDM (W6) dapat diminimalkan serta mampu menangkap peluang keinginan masyarakat menyewa tanah pemda (O1), kemajuan ilmu teknologi di era saat ini (O3), dan dapat meningkatkan penerimaan PAD (O5) dapat dimanfaatkan. Karena itu sangat memungkinkan Pemda meningkatkan kualitas sumber daya manusia dalam rangka meningkatkan penerimaan retribusi daerah.

3). Menetapkan Sanksi Bagi Wajib Retribusi Yang Melanggar.

Pengenaan sanksi disini dapat berupa denda berdasarkan lama tunggakan pembayaran sewa, hal ini di harapkan dapat mengurangi penunggakan pemabayaran sewa tanah yang dilakukan oleh wajib retribusi. Dengan perbaikan 
kualitas SDM kelemahan internal dapat diminimalisir sehingga pelaksanaan sanksi dapat berjalan sebagaimana mestinya.

3. Strategi Strenght-Threats (ST)

Strategi yang menggunakan kekuatan untuk mengatasi ancaman dalam pengelolaan retribusi pemakaian kekayaan daerah, antaranya adalah:

1). Bekerjasama Dengan Dinas - Dinas Terkait.

Upaya ini dilakukan untuk menghadapi berbagai ancaman yang dihadapi seperti masih ada tanah pemda yang masih bersengketa (T2), tanah pemda kurang produktif (T3) dokumen tanah yang belum lengkap (T4), dan tanah pemda yang belum bersertifikat (T7). Ini semua tentu berkaitan dengan peraturan daerah (S1), pembagian tugas yang jelas (S2), dan ketersediaanya aset pemda (S3). Adapun dinas atau instansi yang terkait adalah dinas pertanian dan BPN. Kerjasama dengan dinas pertanian dalam rangka penilaian sewa tanah pertanian dan juga dalam rangka memberikan solusi tentang petani gagal panen. Kemudian kerjasama dengan BPN dalam rangka sertifikasi tanah-tanah Pemda.

2). Melengkapi dokumen kepemilikan tanah pemda.

Banyaknya tanah Pemda yang belum memiliki sertifikat, mengharuskan Pemda segara melakukan upaya melengkapi dokumen-dokumen yang dibutuhkan untuk pensertifikatan tanah tersebut, demi keamanan aset daerah. Adanya ancaman berupa sengketa tanah pemda (T2), dokumen kepemilikan tanah yang belum lengkap (T4), adanya masyarakat yang mengklaim tanah pemda (T5), dan tanah yang belum memiliki sertifikat (T7), maka strateginya segera melakukan upaya dalam melengkapi dokumen kepemilikan tanah milik pemda dengan memanfaatkan kekuatan yang dimiliki seperti pembagian tugas yang jelas (S2), ketersediaan aset tanah (S3), adanya sarana dan prasarana
(S4), dan adanya sistem pengamanan aset yang kuat (S5).

4. Strategi Weaknesses - Treahts (WT)

Strategi ini dilakukan dengan meminimalkan kelemahan dan menghindari ancaman dalam pengelolaan aset daerah, dengan beberapa tindakan sebagai berikut:

1). Optimalisasi Inventaris Aset Daerah. Inventarisasi aset daerah khususnya tanah yang dimaksudkan untuk memperoleh informasi yang akurat, lengkap dan mutakhir mengenai kekayaan yang dimiliki atau dikuasai oleh Pemda Lombok Barat. Demi tercapainya tujuan peningkatan penerimaan retribusi daerah, maka perlu melakukan optimalisasi inventaris aset tanah pemda dengan mengatasi kelemahan internal yang dimiliki seperti belum optimalnya kegiatan inventarisasi aset tanah pemda (W1), minimnya SDM untuk inventarisasi (W2), tarif sewa tanah yang masih rendah (W4), dan lemahnya kualitas SDM (W6). Padahal dengan inventarisasi aset tanah dapat mengatasi ancaman-ancaman yang dihadapi Pemda seperti banyaknya objek tanah yang beralih fungsi (T1), adanya tanah sengketa (T2), tanah kurang produktif (T3), dokumen kepemilikan tanah belum lengkap (T4), adanya pengklaiman tanah pemda oleh pihak ketiga (T5), dan ada tanah pemda yang belum memiliki sertifikat (T7). Hasil dari inventarisasi ini dapat dijadikan dasar dalam pembuatan kebijakan dan pengendalian yang akurat terkait dengan pengelolaan retribusi pemakaian kekayaan daerah, disamping untuk pengamanan barang milik daerah.

2). Meningkatkan Tarif Sewa Tanah.

Peningkatan tarif sewa lelang tanah perlu ditinjau kembali paling tidak 3 tahun sekali, dengan memperhatikan indeks harga dan perkembangan ekonomi. Unttuk itu perlu strategi peningkatan tarif sewa tanah pemda untuk mengatasi 
kelamahan yang dimiliki seperti belum optimalnya kegiatan inventarisasi (W1), masih rendahnya tarif sewa tanah yang ditetapkan (W4), dan kurangnya kualitas SDM tentang tarif sewa dan kurangnya sosialisasi tentang kenaikan tarif sewa (W6) dan juga dapat mengatasi ancaman yang dihadapi berupa tanah yang kurang produktif (T3) dan keengganan masyarakat untuk kenaikan tarif sewa tanah (T6).

3). Meningkatkan Pemafaantan Aset.

Strategi meningkatkan pengawasan aset dilakukan dengan mempertimbangkan kelemahan internal yang dimiliki Pemda berupa belum optimalnya inventarisasi aset tanah pemda yang membuat pemda sendiri tidak tahu dimana tanah pemda yang disewakan sehingga tidak bisa mengawasi pemanfaatan aset tersebut (W1), minimnya SDM untuk mengawasi tanah pemda (W2), dan belum dilaksanakannya proses pengawasan tanah pemda (W5), sehingga sangat perlu Pemda melakukan strategi peningkatan pengawasan pemanfaatan aset tanah. Dengan demikian strategi tersebut dapat mengatasi ancaman yang dihadapi Pemda yaitu adanya sengketa tanah (T2), dan klaim tanah pemda oleh pihak tertentu (T5).

\section{Penentuan Prioritas Strategi}

Merumuskan strategi dilakukan setelah isu-isu strategis yang dihadapi oleh organisasi berhasil diidentifikasi. Berdasarkan analisis SWOT, dapat diidentifikasi isu-isu strategis sebagaimana telah diuraikan sebelumnya. Pada dasarnya isu-isu strategis merupakan problem yang membutuhkan pemecahan masalah. Pemecahan masalah yang dimaksud disini adalah strategi yang perlu dikembangkan untuk mengatasi atau mereduksi permasalahan yang ditemukan melalui penelitian di lapangan. Dengan teridentifikasinya isu-isu strategis tersebut, maka tindakan yang dapat diambil oleh Pemda Lombok Barat guna meningkatkan pendapatan retribusi pemakaian kekayaan daerah dapat diformulasikan ke dalam strategi-strategi sesuai dengan isu-isu strategis yang ada. Untuk itu strategi yang berpotensi dapat diambil dan dikembangkan dengan memperhatikan isu-isu strategis tersebut, yaitu: strategi SO dimana strategi yang diciptakan dengan menggunakan kekuatan untuk memanfaatkan peluang didapatkan strategi berupa memanfaatkan teknologi dalam membantu pengelolaan retribusi pemakaian kekayaan daerah. Kemudian strategi WO dimana strategi yang diciptakan dengan meminimalkan kelemahan untuk memanfaatkan peluang didapatkan strategi yaitu, meningkatkan jumlah SDM dan kualitasnya, dan penetapan sanksi. Ada juga strategi ST dimana strategi yang diciptakan dengan menggunakan kekuatan internal untuk mengatasi ancaman eksternal dan didapatkan isu strategis berupa kerjasama dengan dinas-dinas terkait dan Pemda harus segera melengkapi dokumendokumen kepemilikan tanahnya. Kemudian isu strategis WT dimana diciptakan dengan meminimalkan kelemahan internal dan mengatasi ancaman eksternal didapatkan strategi berupa Pemda segera melakukan inventarisir aset berupa tanah Pemda, meningkatkan tarif sewa tanah Pemda, dan meningkatkan pengawasan pemanfaatkan aset tanah Pemda.

Setiap strategi alternatif yang muncul kemudian di cari tingkat priorotas atau strategi alternatif yang harus segera untuk ditindak lanjuti dalam rangka peningkatan reribusi pemakaian kekayaan daerah dengan cara menambahkan unsur keterkaitan indikator SWOT yang telah diberi skor, sehingga di dapatkan nilai peringkat yang mana semakin tinggi nilai maka strategi alternatif tersebut merupakan strategi alternatif yang harus 
segera ditindaklanjuti oleh Pemda untuk bisa mengoptimalkan penerimaan pendapatan retribusi pemakaian kekayaan daerah.

Tabel 7. Penentuan Proritas Strategis Peningkatan Retribusi Pemakaian Kekayaan Daerah

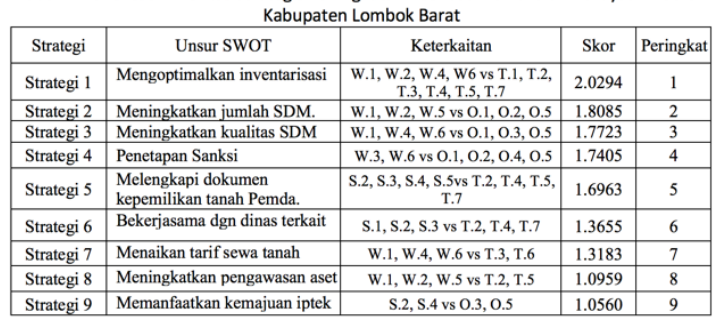

Dengan hasil tersebut selanjutnya bisa ditentukan tindakan untuk mengatasi isu strategis yang ada. Tindakan yang diambil merupakan strategi dalam meningkatkan pendapatan retribusi pemakaian kekayaan daerah/tanah di Kabupaten Lombok Barat. Sesuai urutan penilaian, maka strategi yang dapat dirumuskan untuk meningkatkan penerimaan retribusi pemakaian kekayaan daerah tersebut adalah; Mengoptimalkan invetarisasi, Meningkatkan jumlah dan kualitas SDM, Penetapan sanksi, Melengkapi dokumen kepemilikan tanah, Bekerjasama dengan dinas terkait, Menaikan tarif sewa tanah, Meningkatkan pengawasan pemanfaatan asset, dan Memanfaatkan kemajuan ilmu teknologi.

\section{KESIMPULAN}

Dari uraian diatas, strategi yang tapat terkait dengan upaya peningkatan penerimaan retribusi pemakaian kekayaan daerah/tanah di Kabupaten Lombok Barat menghasilkan beberapa strategi sebagai berikut:

Strategi Strenght-Opportunity (SO), Strategi yang menggunakan kekuatan untuk memanfaatkan peluang dalam pengelolaan retribusi penggunaan kekayaan daerah, dilakukan dengan beberapa tindakan yaitu: Memanfaatkan kemajuan ilmu teknologi dalam rangka mendukung pengelolaan retribusi pemakaian kekayaan daerah,
Strategi Weaknees-Opportunity (WO), strategi yang dijalankan dengan meminimalkan kelemahan untuk memanfaatkan peluang dalam pengelolaan retribusi pemakaian kekayaan daerah, sehingga strategi yang dapat dilakukan antaranya; Meningkatkan kuantitas dan kualitas SDM yang berkaitan dengan pengelolaan retribusi pemakaian kekayaan daerah; Menetapkan sanksi yang tegas bagi pelanggar wajib retribusi.

Strategi Strenght-Threats (ST), strategi yang menggunakan kekuatan untuk memanfaatkan peluang jangka panjang dalam pengelolaan retribusi pemakaian kekayaan daerah, dengan strategi: Bekerjasama dengan pihak terkait dalam mendukung proses peningkatan retribusi pemakaian kekayaan daerah; Melakukan pensertifikatan tanah yang belum memiliki sertifikat.

Strategi Weaknesses-Threats (WT), strategi yang dilakukan dengan cara meminimalkan kelemahan dan menghindari ancaman dalam pengelolaan aset daerah berupa tanah. Strategi dapat dilakukan dengan beberapa tindakan sebagai berikut: Menginventarisir aset-aset Pemda yang belum terdata; Meningkatkan tarif sewa tanah sesui dengan kondisi perekonomian saat ini; Meningkatkan pengawasan pemanfaatan tanah.

Dengan keadaan diatas, dapat direkomendasikan beberapa hal antaranya;

$\approx$ Perlu perhatian serius Pemda Lombok Barat untuk inventarisasi aset baik fisik maupun legal/yuridisnya. Dengan demikian akan dapat mengetahui secara pasti 
jumlah dan nilai kekayaan daerah yang dimiliki.

$\approx$ Melengkapi dokumen-dokumen kepemilikan aset demi keamanan aset milik Pemda lebih terjamin, sehingga akan lebih pasti prediksi pendapatan daerah melalui retribusi pemakaian kekayaan daerah tersebut.

$\approx$ Pemerintah perlu meningkatan jumlah dan kualitas SDM untuk bidang pengelolaan aset daerah demi peningkatan retribusi daerah, melaksanakan pelatihan berkala dalam rangka peningkatan kualitas SDM khususnya penguasaan bidang ilmu pengetahuan dan teknologi.

$\approx$ Melakukan digitalisasi aset tanah pemda guna dapat mempermudah pengawasan aset tanah pemda dan mempermudah mengetahui posisi tanah yang disewakan serta luasan tanah yang disewakan kepada masyarakat.

\section{DAFTAR PUSTAKA}

Budianto. 2014. Analisis Pengaruh Retribusi Penggunaan Kekayaan Daerah, Retribusi Pelayanan Kepelabuhan, Retribusi Izin Usaha Perikanan Provinsi Kepulauan Riau Terhadap Retribusi Daerah Provinsi Kepulauan Riau.Fakultas Ekonomi dan Bisnis Universitas Maritim Raja Ali Aji.

Burhan. Penjelasan UU Otonomi Daerah Beserta Pelaksanaannya. 26 Desember 2018. http://satujam.com/uu-otonomidaerah/.

Fajri, Ahmad, 2017. Pengelolaan Aset Tanah Daerah Untuk Meningkatkan Pendapatan Asli Daerah Kota Malang Perspektif Ekonomi Islam.Universitas Islam Negeri Maulan Malik Ibrahim.

Ningrum, Dian Hanggarani. 2010.
Kontribusi Retribusi Penggunaan Kekayaan Daerah Kota Surakarta Tahun Anggaran 2007 - 2009.Fakultas Ekonomi dan Bisnis Universitas Sebelas Maret.

Putra, Boby Fandy, dkk. 2013. Analisis Efektifitas Penerimaan dan Kontribusi Daerah Terhadap Pendapatan Asli Daerah.Fakutas Ilmu Administrasi Universitas Brawijaya.

Rahmayanti. 2013. Strategi peningkatan Retribusi (Jasa) Pasar Niaga Daya Di Kota Makassar.Fakultas Sosial Dan Ilmu Politik.Universitas Hassanudin.

Suryani, Irma. 2009. Analisis Strategi Peningkatan Retribusi Pasar Di Kabupaten Pekalongan.Magister Ilmu Administrasi Uniersitas Diponogoro.

Siregar, Doli.2004. Manajemen Aset. Gramedia Pustaka Utama, IKPI.Jakarta.

Sugianto. 2007. Pajak dan Retribusi Daerah. Jakarta: Cikal Sakti.

Sugiyono.2018. Metode Penelitian Pendidikan (pendekatan kuantitatif, Kualitatif dan RED). Bandung, Alfabeta.

Tripmo, Tedjo \& Udan. 2005. Manajemen Strategi. Bandung. Rekayasa Sains.

Undang - undang No.23 Tahun 2014 Tentang Otonomi Daerah

Undang - Undang No.33 Tahun 2004 Tentang Dana Perimbangan Pemerintah Pusat dan Pemerintah Daerah

Peraturan Daerah No. 28 Tahun 2009 tentang Pajak Daerah dan Retribusi Daerah

Peraturan Pemerintah nomor 66 tahun 2001 tentang Retribusi Daerah

Peraturan Daerah Kabupten Lombok Barat No 4 tahun 2011 tentag Retribusi Jasa 
Usaha.

Wardani, Retnanda Kresna. 2010. Kontribusi Retribusi Pemakaian Kekayaan Daerah Di Bandingkan Dengan Retribusi Rumah Potong Hewan Terhadap Pendapatan Asli Dearah Kota Surakarta.Fakultas Ekonomi Universitas Sebelas Maret.

Wahyuni, Eni. 2017. Optimalisasi Penerimaan Retribusi Penggunaan Kekayaan Daerah.Fakultas Ekonomi dan Bisnis Uniersitas Pembangunan Veteran.

Widiantari, Ni Luh Putu Eka.I Gusti Agung Mas Rwa Jayantiari.2016.
Optimalisasi Pemanfaatan Asset Daerah Dalam Rangka Peningkatan Pendapatan Asli Daerah Kota Denpasar.Fakultas Ekonomi Dan Bisni versitas Udayana

_Badan Pengelolaan Kuangan dan Asset Daerah. Laporan Keuangan Badan Pengelolaan Kekuangan dan Asset Daerah tahun 2012.

_Badan Pengelolaan Kuangan dan Asset Daerah.Laporan Keuangan Badan Pengelolaan Kekuangan dan Asset Daerah tahun 2013-2017. http://bpkad.lombokbaratkab.go.id/ di akses tgl 19 januari 2019 jam 23:57 WIB 